Vol. 14 (2005): 34-43.

\title{
Sources of acidity and metals in a stream draining acid sulphate soil, till and peat, western Finland, revealed by a hydrochemical and sulphur isotope study
}

\author{
Mats Åström \\ Department of Biology and Environmental Science, Kalmar University, SE-39182 Kalmar, Sweden, \\ e-mail:mats.astrom@hik.se \\ Baruch Spiro \\ Department of Mineralogy, The Natural History Museum, Cromwell Road, London SW7 5BD, \\ United Kingdom
}

The main aim of this study was to determine, during extreme hydrological conditions, the source(s) of acids, sulphate and metals (alkali and alkaline earths) in the Munsala stream (western Finland) draining mainly acid sulphate soil, peat and till. Samples were collected at 6 sites along the main stem on 3 high-flow and 3 low-flow events, and were analysed for the required chemical and isotopic variables. The acid sulphate soils (located under farmland) had a large impact on the stream as indicated by $\mathrm{pH}$ values occasionally down to 4.0, moderately to strongly increased concentrations of inorganic solutes, and a high acid $\mathrm{SO}_{4}{ }^{2-}$ load characterised by negative $\delta^{34} \mathrm{~S}_{\text {(sulphate) }}$ values. In addition, the forested areas underlain mainly with till and peat released low $\mathrm{SO}_{4}{ }^{2-}$ but low $\mathrm{pH}$ waters (down to at least 4.6) during high flows, indicating the importance of humic acids in controlling the $\mathrm{pH}$. These humic acids flocculated abundantly in the middle/ lower reaches as a result of interaction with acid sulphate water. Therefore, not only the farmland acid sulphate soils but also the organic-rich soils/horizons in the forested areas contribute to water-quality deterioration.

Key words: acid sulphate soil, alkali metals, alkaline earth metals, sulphur, ditching, sulphur isotopes, land use, catchment area 
Vol. 14 (2005): 34-43.

\section{Introduction}

The geochemical atlas of stream waters in Finland and the results of several other hydrochemical studies show that a large number of small and medium-sized streams in the coastal areas of Finland are acidified and have exceptionally high concentrations of many metals (Edén and Björklund 1993, Palko and Yli-Halla 1993, Weppling 1993, Åström and Björklund 1995, Lahermo et al. 1996, Edén et al. 1999, Åström and Spiro 2000). It is also known, that the source of these high acid and metal levels is widespread acidic soils commonly referred to as acid sulphate (AS) soil but classified mostly as Sulfic Cryaquepts or Typic Sulfaquepts (Palko 1994, Palko and Weppling 1995, Yli-Halla 1997, Yli-Halla et al. 1999). These soils have developed by oxidation of Holocene sulphide-rich sediments deposited when the coastal zone was still covered by the brackish Baltic Sea and its predecessor; the Litorina Sea. While this oxidation process and the material being oxidised are entirely natural, the extent of the oxidation (and thus acidification) has been hugely increased as a result of water table drawdown caused by intensive agricultural drainage of these Brackish-water sediments (e.g. Wiklander et al. 1950, van Breemen 1973, Öborn 1989, van Breemen 1993). Thus, it is largely the modern agricultural activities that are responsible for the poor water quality of the area.

Despite this knowledge, many important potential controls of water quality in the area have not been adequately investigated. These include both the specific and the combined effects of hydrological conditions, climatic variables and other adjacent nearby organic-rich and organic-poor soils. In addition, the concentration of many trace elements has been determined only to a limited extent in these waters. As a consequence, we do not as yet have the data and information required in order to develop cost-effective management strategies and to model the environmental impact of the AS soils.

The main aim of this study was to determine, during extreme hydrological conditions, the source(s) of acids, sulphate and metals (alkali and alkaline earths) in the Munsala stream (western Finland) draining mainly AS soil, till and peat. Previous studies have shown that this stream is seriously affected by AS soil and has a highly variable water quality (Åström and Björklund 1996, Åström 2001a, b).

\section{Catchment description}

The Proterozoic $1.8 \mathrm{Ga}$ old granitoidic bedrock in the $107 \mathrm{~km}^{2}$ large Munsala-stream catchment is overlain to a large extent with till, peat and sand, which are used for forestry (Fig. 1). A major part of these forested areas is artificially drained by a network of approximately $1 \mathrm{~m}$ deep open surface ditches reaching the organic (peat) and mineralsoil layers underneath the forest topsoil. These ditching activities have been carried out during the last few decades in order to release the excess surface water and thereby improve the growth conditions for the trees.

Fine-grained sulphide-bearing sediments are exposed along the main stem in particular but to some extent also in peripheral parts of the catchment. They have sulphur (S) concentrations of approximately $0.5 \%$ (Åström and Björklund 1996) and were deposited mainly during the Litorina Sea period. In the top 1-2 $\mathrm{m}$ of these sediments, AS soil having $\mathrm{pH}$ values $<4$ and high $\mathrm{SO}_{4}{ }^{2-}$ concentrations have developed (Fig. 1). This soil type has formed as a result of extensive ditching operations which have been, and are still being, carried out in order to turn these waterlogged lands into productive farmland. Hence, the entire catchment has, more or less, been artificially drained, which has changed the pattern of natural drainage. Other local anthropogenic impacts are relatively minor as within the catchment the population is sparse $(<1000$ persons distributed in a few small villages), the industrial activity is small and the traffic load is low.

The climatic and hydrological conditions in the region are as follows: In summer (June-August) there is continuous daylight, a mean temperature 
Fig. 1. Sites of water sampling (M1-M6) in the Munsala stream. The indicated distribution of acid sulphate soil is not based on detailed soil mapping but on the distribution of fine-grained sediments (Åström and Björklund 1996) and general field observations by the authors. These soils are entirely overlain by farmland. The till, peat and glaciofluvial deposits (sand), not separated in the map, are overlain mostly by forests.

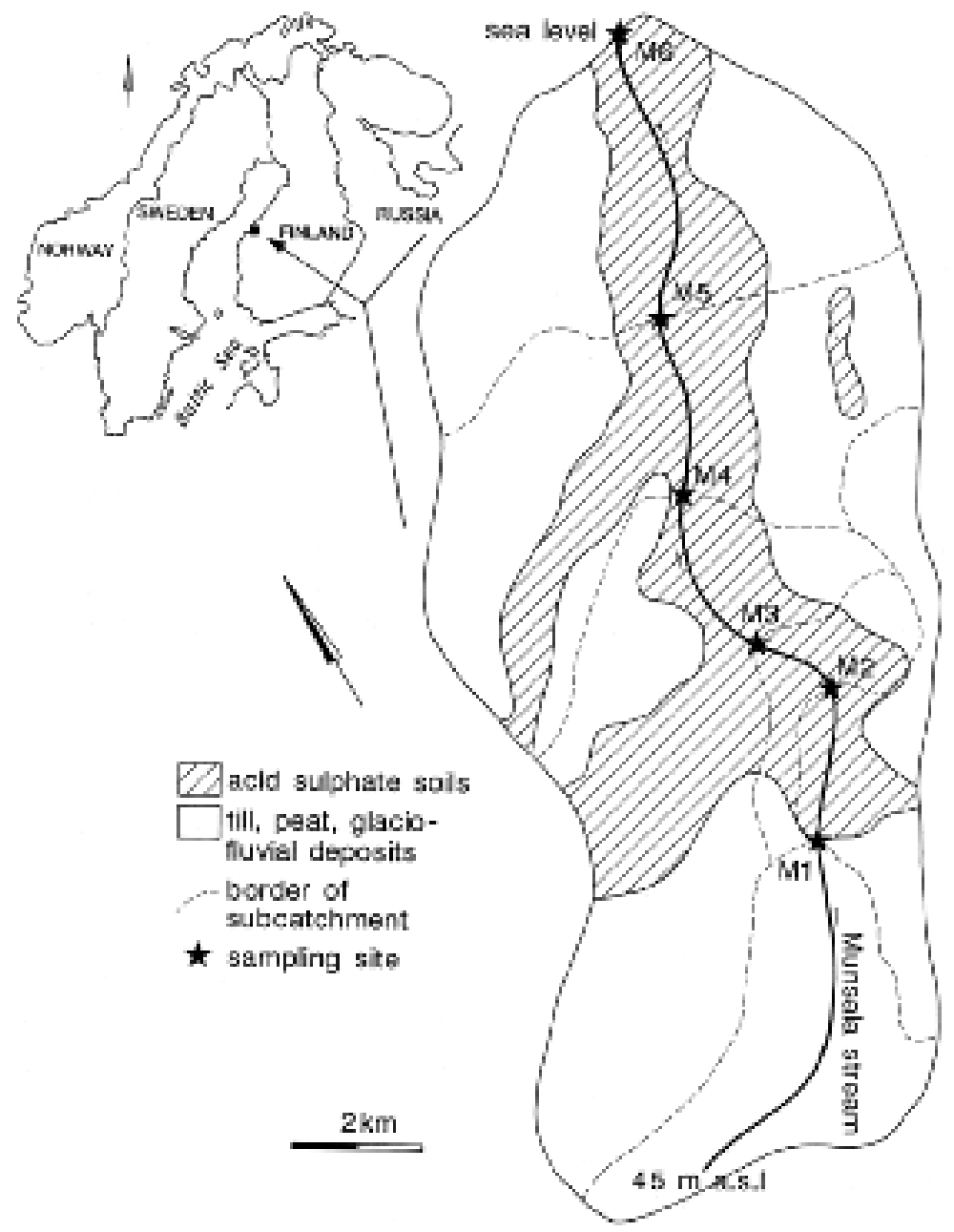

The mean annual precipitation in the area is approximately $500 \mathrm{~mm}$, of which part falls as snow.

\section{Methods}

A total of 6 sampling sites (M1-M6) along the main stem of Munsala stream were included in the sampling programme (Fig. 1). Site M1, which drains the forested upper $13 \%$ of the catchment un- 
Vol. 14 (2005): 34-43.

derlain with non-AS soil (till, peat, sand), is located at the point where the main stem reaches the AS soil (Fig. 1). From M2 to M6 there is a gradual increase in the relative proportion of AS soil in the catchment, i.e. $11 \%, 18 \%, 27 \%, 30 \%$ and $31 \%$. Water samples were collected during high-water flow in autumn (November) 1996 (HA-I), autumn (November) 1997 (HA-II) and summer (June) 1998 (HS), and during low-water flow in summer (August) 1995 (LS-I), autumn (September) 1997 (LA) and summer (July) 1998 (LS-II). A discussion of why these sampling dates were chosen are found in Åström 2001a, b. Discharge was not measured, but it is in the order of $1001 \mathrm{~s}^{-1}$ during low flows and two orders of magnitude higher at high flows.

Water samples for multielement analyses were acidified to a $\mathrm{pH}<2$ with concentrated $\mathrm{HNO}_{3}(\mathrm{Su}-$ prapur quality, Merck) and analysed with a Perkin Elmer-Sciex ELAN 6000 (inductively coupled plasma - mass spectrometry). The results of alkali and alkaline earth metals, i.e. barium (Ba), calcium $(\mathrm{Ca})$, potassium $(\mathrm{K})$, lithium $(\mathrm{Li})$, magnesium $(\mathrm{Mg})$, sodium $(\mathrm{Na})$, rubidium $(\mathrm{Rb})$ and strontium $(\mathrm{Sr})$, in this text referred to as AAEMs, are presented in this paper. Analyses of duplicates showed that for each metal, the combined sampling and analytical error was significantly ( $\alpha=0.01)$ smaller than the overall concentration variability. Hence, any patterns and trends of these metals in the data set are due to a true representation of variations between samples and not to sampling or analytical errors. The median ratio of the metal concentration in filtered $(0.45-\mu \mathrm{m}$ polycarbonate screen filters Nuclepore) to unfiltered samples was close to one (range $=0.98-1.03$ ) which means that the concentrations presented below, for unfiltered samples only, are representative also in general for the "dissolved phase" (true solution + particles $<0.45$ $\mu \mathrm{m})$.

Unfiltered water samples collected in glass bottles and kept in darkness at $+4^{\circ} \mathrm{C}$ were analysed, after any organic particles had settled to the bottom of the sample bottle, for total organic carbon (TOC) concentrations with a Shimadzu Total Carbon 5050 Analyzer. Experience during more than 20 years of studies of organic (humic) sub- stances in Finnish surface waters have shown that: (1) the organics are stable for up to several months if the water is stored in dark at a few degrees above zero, (2) the recorded TOC concentrations are in general only marginally higher than and correlate strongly with the dissolved organic carbon (DOC) concentrations.

Samples for S-isotope analysis (1-2 1) were collected in polyethylene bottles and acidified with $\mathrm{HCl}(\mathrm{pH} \sim 2)$. After preconcentration by evaporation, $\mathrm{SO}_{4}{ }^{2-}$ was precipitated with $6 \% \mathrm{BaCl}_{2}$ solution. The $\mathrm{BaSO}_{4}$ precipitate was collected on quartz microfibre filter (Whatman), burned at $500^{\circ} \mathrm{C}$ to oxidise any organic compounds and weighed for a quantitative determination of $\mathrm{SO}_{4}{ }^{2-}$ concentrations. $\mathrm{SO}_{2}$ was produced by reducing $\mathrm{BaSO}_{4}$ with $\mathrm{Cu}_{2} \mathrm{O}$ under vacuum at $1175^{\circ} \mathrm{C}$, and purified by collecting any $\mathrm{H}_{2} \mathrm{O}$ in a cold acetone trap $\left(-50^{\circ} \mathrm{C}\right)$ and separation of $\mathrm{SO}_{2}$ from $\mathrm{CO}_{2}$ in a n-pentane trap (Coleman and Moore 1978). The isotopic composition was determined on a VG SIRA 10 mass spectrometer and is expressed in parts per thousand $(\%$ o) relative to Vienna Canyon Diablo Troilite $\left(\delta^{34} \mathrm{~S} V-\mathrm{CDT}\right)$. Analysis of the reference materials IAEA-S-1 and NBS 122 (IAEA - International Atomic Energy Agency, NBS - National Bureau of Standards) gave values of $-0.3 \%$ and $+0.15 \%$ o respectively. The overall analytical reproducibility of the $\mathrm{S}$-isotope analysis and the $\mathrm{SO}_{4}{ }^{2-}$ determination was $0.2 \%$ and $0.3 \mathrm{mg} \mathrm{l}^{-1}$ respectively.

\section{Results and discussion}

\section{The headwater}

In the headwater (M1), to which forested areas underlain with non-AS soils drain (Fig. 1), the stream water was strongly coloured and carried high TOC concentrations, $34-50 \mathrm{mg} \mathrm{l}^{-1}$ (Fig. 2). This is a result of an abundance of dissolved humic substances leached from patches of thin peat layers (Kortelainen and Saukkonen 1992, Kortelainen 1993, Kortelainen and Saukkonen 1998) and the humus horizon of the forest mineral-soils. In contrast, the 
Åström, M. \& Spiro, B. Sources of acidity and metals in an acid sulphate soil, till and peat
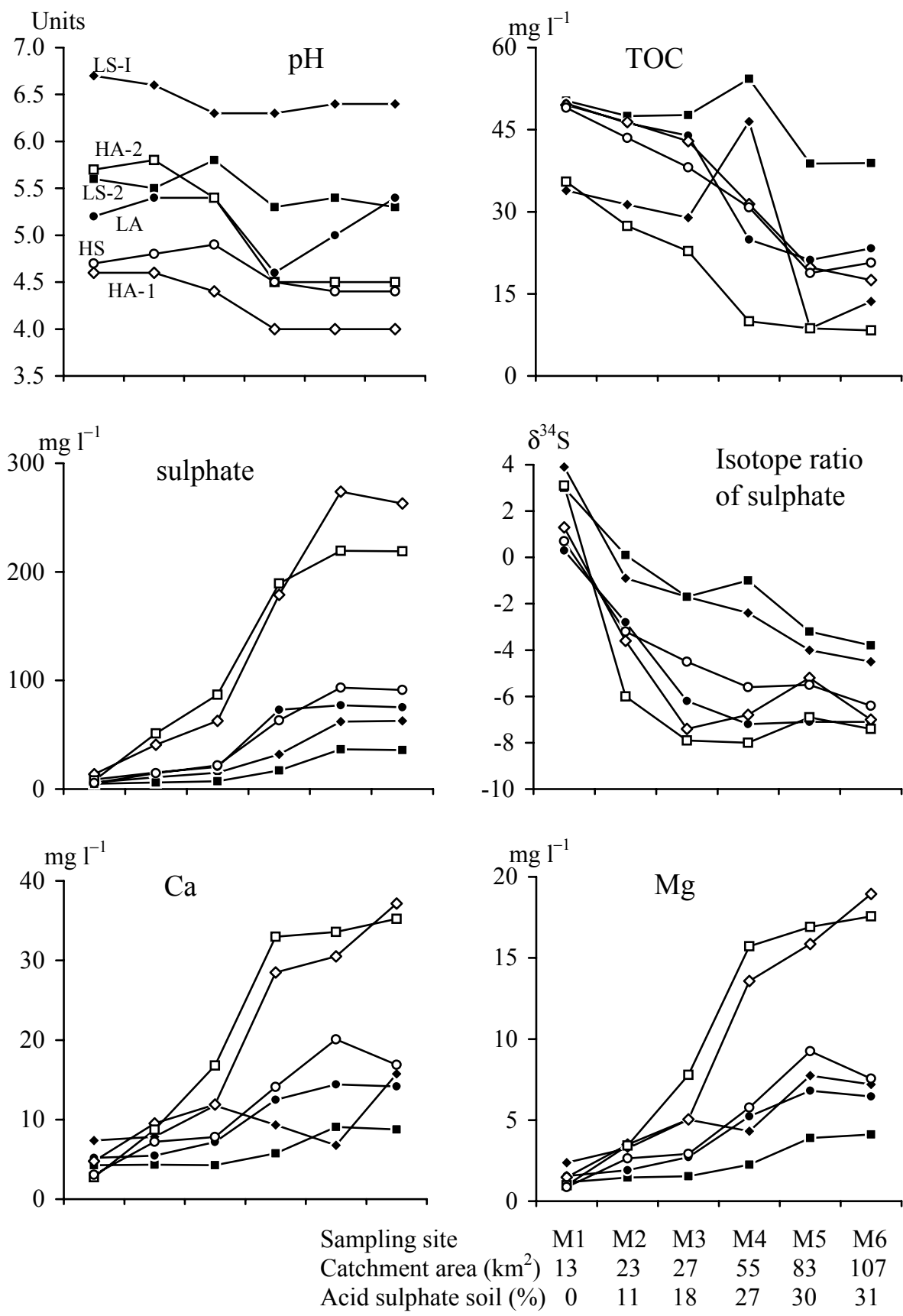

Fig. 2. Downstream variations in S-isotope ratios and concentrations of chemical elements in the Munsala stream during 3 high-flow periods indicated with open symbols (HA-1: November 1996; HA-2: November 1997; HS: June 1998) and 3 low-flow periods indicated with filled symbols (LS-I: August 1995; LS-2: July 1998; LA: September 1997). 
Vol. 14 (2005): 34-43.
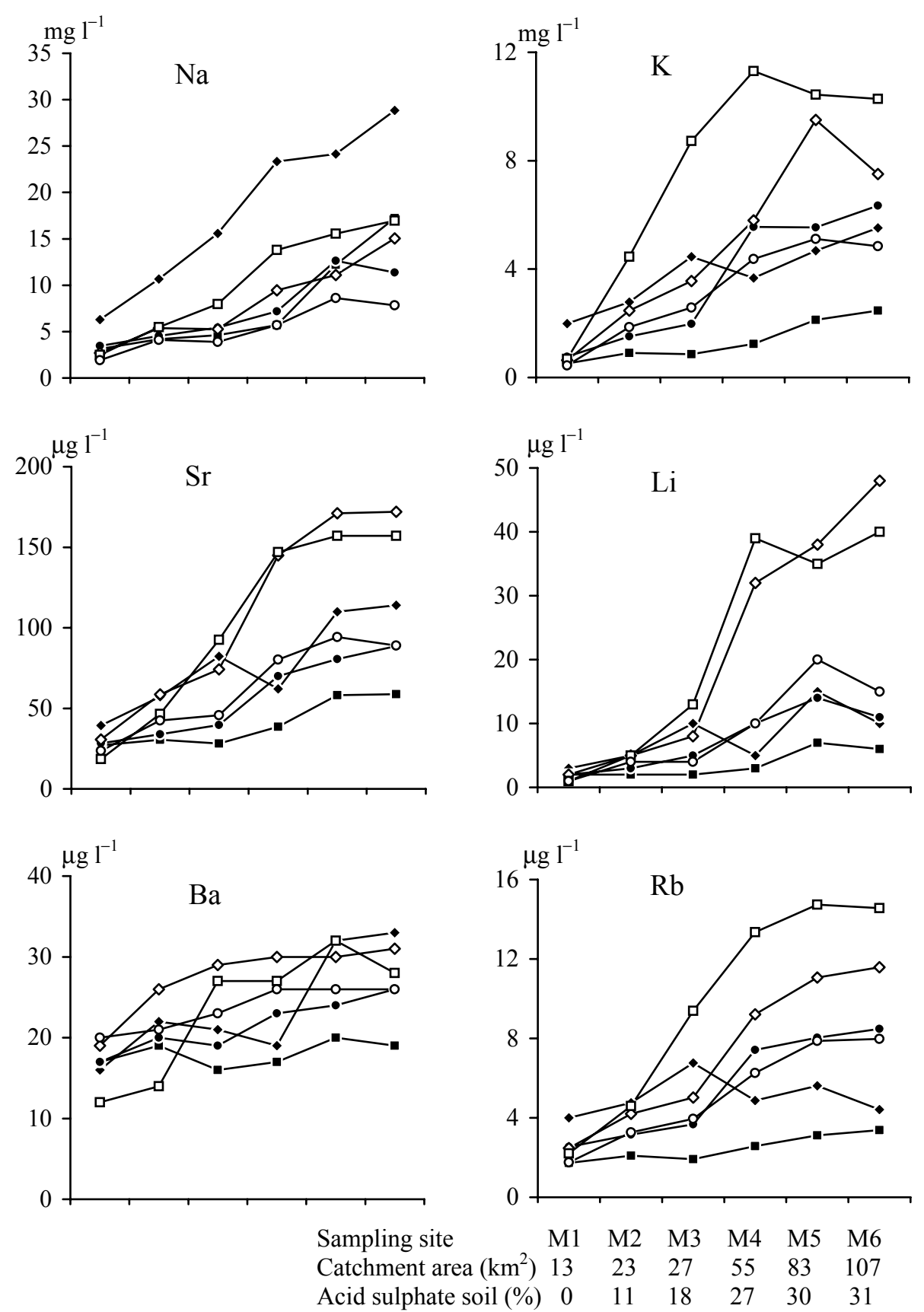

Fig. 2. continues. 
concentrations of $\mathrm{SO}_{4}{ }^{2-}$ and AAEMs were low (Fig. 2), i.e. on levels typical for non-polluted and non-AS soil affected Finnish forests streams (e.g. Lahermo et al. 1995). The $\delta^{34} \mathrm{~S}_{\text {(sulphate) }}$ values were positive, 0.3-3.9\% V-CDT (Fig. 2), which shows that the main, however unidentified, sulphur $\left(\mathrm{SO}_{4}{ }^{2-}\right)$ source(s) is enriched in the heavy isotope. Possible sources are till carrying primary sulphides, peat and humus horizons carrying organic$\mathrm{S}$, and atmospheric deposition carrying $\mathrm{SO}_{4}{ }^{2-}$ of variable origin.

The $\mathrm{pH}$ varied between 4.6 and 6.7 (Fig. 2). A plot of TOC concentrations versus pH (Fig. 3) show that while the overall correlation between these variables is rather weak, the correlations are strong when low and high water flows are considered separately. This is due to the $\mathrm{pH}$ being approximately one unit lower at high than at low flows at similar TOC concentrations. In contrast, there were no correlations between the $\mathrm{pH}$ and $\mathrm{SO}_{4}{ }^{2-}$ concentrations. These trends show that the main $\mathrm{pH}$ control in the headwater is organic (humic), acids and not sulphuric acid. This is consistent with the commonly small contribution of strong acids to the total acidity load of humus-rich surface waters in rural areas of the boreal zone (Kortelainen and Mannio 1988, 1990, Kortelainen and Saukkonen 1995, Laudon et al. 2000). The reason as to why the $\mathrm{pH}$ is depressed at high flow is that on such periods the hydrological activation of the near-surface layers results in effective extraction of humic acids and a decrease in the acid neutralising capacity of the exiting water (Laudon and Bishop 1999, Bishop et al. 2000, Laudon et al. 2000).

\section{Downstream patterns during high flows}

On each high-flow event, there was a decolouring of the water and an increase in suspended visible humic (or humic-rich) flocks towards the outlet, accompanied by a downstream decrease in the TOC concentrations (Fig. 2). This is explained by: (1) flocculation of humic substances as a result of interaction with high-valence cations leached from AS soils (Åström and Björklund 1996, Åström and
Corin 2000), and (2) dilution by AS soil runoff which is low in dissolved humus (TOC commonly $<10 \mathrm{mg} \mathrm{l}^{-1}$; Åström and Björklund 1995).

In the autumn there was a strong and in summer a moderate downstream increase in the concentrations of $\mathrm{SO}_{4}{ }^{2-}$ and AAEMs, except for $\mathrm{Ba}$ which increased downstream only weakly (Fig. 2). This spatial pattern correlates strongly to the downstream increase in the AS soil cover (Fig. 2), indicating this soil as the source. Evidence of this is provided by several previous studies ( $⿱$ ström and Björklund 1995, Åström and Åström 1997, Åström and Spiro 2000) showing that from Finnish AS soils, $\mathrm{Ba}$ is leached only to a small extent while $\mathrm{SO}_{4}{ }^{2-}$ and the other studied AAEMs are leached abundantly (runoff concentrations of $\mathrm{SO}_{4}{ }^{2-}$ up to $3000 \mathrm{mg}^{-1}$, Na 300, Ca 250, Mg 200, K 50, Sr 1.5, Li 0.5 and $\mathrm{Rb} 0.13$ have been identified). The mechanism responsible for the general increase in AAEMs downstream is as follows: In summer, when the AS soils are characterised by elevated temperatures and low ground-water tables, sulphate (sulphuric acid) is produced by the oxidation of sulphides and AAEMs are released in cation-exchange and weathering reactions. This creates a substantial soluble pool, a large part of which is mobilised when the soils are flushed in the subsequent autumn and the remaining part of which is mobilised in the following spring and early summer (as at HS). The reason for the contrasting behaviour of $\mathrm{Ba}$ may be formation in the soils of highly insoluble $\mathrm{BaSO}_{4}$.

There was a change in the $\delta^{34} S_{\text {(sulphate) }}$ values from positive $(0.3-3.9 \%$ ) in the headwater (M1) to values between -3.6 and $-8.0 \%$ o downstream (Fig. 2). Because there is no question that at the downstream sites (M2-M6) the majority of the $\mathrm{SO}_{4}{ }^{2-}$ originated in the AS soils and that in-stream processes did not shift the $\delta^{34} S_{\text {(sulphate) }}$ values, the recorded downstream $\delta^{34} \mathrm{~S}$ values must be equal to those of the $\mathrm{SO}_{4}{ }^{2-}$ in the AS soil runoff. Thus, the AS soils in the Munsala-stream catchment deliver $\mathrm{SO}_{4}{ }^{2-}$ enriched in ${ }^{32} \mathrm{SO}_{4}{ }^{2-}$. This most likely reflects the fact that the light isotope is favoured in the bacterial reduction processes (Kaplan and Rittenberg 1964, Nakai and Jensen 1964, Hoefs 1997). When metal sulphides were precipitated in the par- 
Vol. 14 (2005): 34-43.

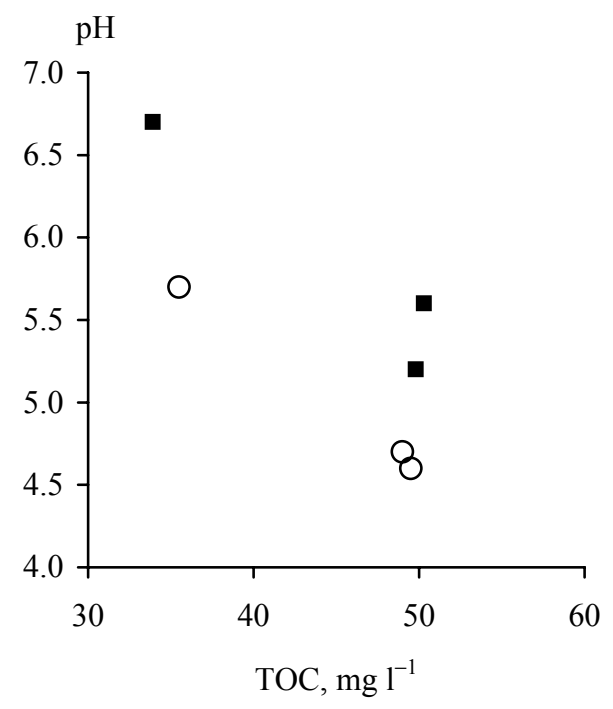

Fig. 3. Relationship between total organic carbon (TOC) concentrations and $\mathrm{pH}$ in the headwater of Munsala stream (site M1) during low-water flows (squares) and high-water flows (circles).

ent (reduced) sediments of the AS soils, they became strongly enriched in ${ }^{32} \mathrm{~S}$ relative to the source (sea water) $\mathrm{SO}_{4}{ }^{2-}$. At present, when sulphate (sulphuric acid) is formed by chemical and biological sulphide oxidation in the AS soils, the $\mathrm{S}$ isotopic fractionation is small or non-detectable (e.g. Rollinson 1993) and consequently the isotopic signature of the sulphides (enriched in ${ }^{32} \mathrm{~S}$ ) is preserved in the $\mathrm{SO}_{4}{ }^{2-}$ which is formed and leached. These $\mathrm{S}$-isotopic trends are in line with the results of Åström and Spiro (2000). However, they found that some Finnish AS soils deliver $\mathrm{SO}_{4}{ }^{2-}$ with positive $\delta^{34} \mathrm{~S}$ values. Such AS soils seems not to exist, or are rare, in the Munsala-stream catchment.

The $\mathrm{pH}$ was on each high-flow event lower at M4-M6 than at M1-M3 (Fig. 2). Along the section where $\mathrm{pH}$ dropped (between M3 and M4) there is an increase in the proportion of AS soil from $18 \%$ to $27 \%$ and a considerable increase in the $\mathrm{SO}_{4}{ }^{2-}$ concentrations in the water (Fig. 2). This seems thus to be the section where excess sulphuric acid from AS soil is leached into the stream resulting in a serious $\mathrm{pH}$ decline of the water downstream.

\section{Downstream patterns during low flows}

During two of the low-flow events (LA and LS-I), there was a downstream decrease in TOC concentrations similar to that during the high-flow events, except at site M4 on LS-I (Fig. 2). On the remaining low-flow event (LS-II), in contrast, the TOC concentrations were high throughout the stream (39-54 $\mathrm{mg} \mathrm{l}^{-1}$ ). Like on the high flows, there was a downstream increase in the concentrations of $\mathrm{SO}_{4}{ }^{2-}$ and AAEM:s (Fig. 2). This downstream increase was, however, similar to or even weaker than on HS, except for $\mathrm{Na}$ which increased similarly to or even more than on any of the high-flow events (Fig. 2). These patterns reflect that: (1) also on low-flow periods AS soil release weathering products, however not at all to the same extent as on high-flow periods, (2) on some low-flow periods (LS-II) the AS soil impact is so small that high TOC concentrations persist throughout the stream (no flocculation) and there is only a marginal downstream increase in $\mathrm{SO}_{4}{ }^{2-}$ and AAEM concentrations, and (3) there is (a detectable) mobilisation of relict brackish water (containing $\mathrm{NaCl}$ ) from the pores of deep soil horizons and/or the upper parent sediment.

On each low-flow event, the $\delta^{34} S_{\text {(sulphate) }}$ values were negative downstream of M1 (except at M2 on LS-II), which is explained by the dominance of AS soil-derived aqueous $\mathrm{SO}_{4}{ }^{2-}$. On the summer low flows, however, the downstream decrease in $\delta^{34} S_{\text {(sulphate) }}$ values was not as strong as on the other events (Fig. 2). A reasonable explanation, as on these two events the $\mathrm{SO}_{4}{ }^{2-}$ concentrations were the lowest (Fig. 2), is mixing dynamics, i.e. the proportion of $\mathrm{SO}_{4}{ }^{2-}$ from AS soil (negative $\delta$ values) was relatively low (although dominating) in comparison to that from forested areas (positive $\delta$ values like in the headwater). However, since these two events are in summer, when in addition to low flow velocity the water temperatures are high, instream biological activity and thus oxygen consumption leading to anoxia and bacterial $\mathrm{SO}_{4}{ }^{2-}$ reduction is possible. This would shift the $\delta^{34} \mathrm{~S}$ values of the remaining aqueous $\mathrm{SO}_{4}{ }^{2-}$ to higher values, as observed, due to the preferential reduction of the lighter isotope by bacteria. The present data 
do not allow however the production of a reliable mixing diagram, and thus quantification of $\mathrm{SO}_{4}{ }^{2-}$ reduction is not possible.

During the low flows, the $\mathrm{pH}$ was considerably higher in the middle/lower (AS soil-affected) reaches than during the high flows, except for the relatively low $\mathrm{pH}$ at M4 on LA (Fig. 2). This occurs because on dry periods the leaching of sulphuric acid from the AS soils is marginal (reflected in relatively low $\mathrm{SO}_{4}{ }^{2-}$ concentrations downstream), the buffering capacity is increased due to water flows predominantly in subsurface layers, and because of the possibility (in summer) of instream $\mathrm{SO}_{4}{ }^{2-}$ reduction and concomitant alkalinity production.

\section{Conclusions}

The Munsala stream is seriously affected by AS soils, as indicated by: (1) $\mathrm{pH}$ values occasionally down to 4.0 even in the present relatively small data set, (2) continuously increased concentrations of inorganic solutes, (3) particularly strong increase in both concentrations and fluxes of inorganic solutes during heavy rains, and (4) a high acid $\mathrm{SO}_{4}{ }^{2-}$ load characterised by negative $\delta^{34} \mathrm{~S}_{\text {(sulphate) }}$ values indicative of bacteriogenic sulphide source. In addition, the forested areas of the headwater (and elsewhere) underlain mainly with till and peat release low $\mathrm{SO}_{4}{ }^{2-}$ but low $\mathrm{pH}$ waters (down to at least 4.6) during high flows, indicating the importance of humic acids in controlling the $\mathrm{pH}$. These humic acids flocculate abundantly in the middle/ lower reaches as a result of interaction with highvalence cations leached from AS soils. From the viewpoint of remedial measures, therefore, it is necessary to consider: (1) the large proton reservoir in both acid organic soils and AS soils within the catchment, (2) the extensive soil leaching during wet periods resulting in high-water flows characterised by low $\mathrm{pH}$ and strongly elevated metal fluxes, (3) coexisting weak organic and strong mineral acids in the stream water, and (4) the formation and downstream transport of suspended humic flocs certainly mixed with inorganic precipitates and elements.

Acknowledgements. Thanks are due to the Academy of Finland, Svenska Kulturfonden, Ella och Georg Ehrnrooths Stiftelse, and Renlunds Stiftelse for financial support to MÅ.

\section{References}

Åström M. 2001a. Hydrological and soil geochemical controls of the abundance and fractionation patterns of rare earth elements in a periodically acidic Boreal stream. Geochemistry - exploration, environment, analysis 1: 101-108.

Åström, M. 2001b. The effect of acid-soil leaching on traceelement abundance in a medium-sized stream, W. Finland. Applied Geochemistry 16: 387-396.

Åström, M. \& Åström, J. 1997. Geochemistry of stream water in a catchment in Finland affected by sulphidic fine sediments. Applied Geochemistry 12: 593-605.

Åström, M. \& Björklund, A. 1995. Impact of acid sulfate soils on stream water geochemistry in western Finland. Journal of Geochemical Exploration 55: 163-170.

Åström, M. \& Björklund, A. 1996. Hydrogeochemistry of a stream draining sulfide-bearing postglacial sediments in Finland. Water, Air and Soil Pollution 89: 233-246.

Åström, M. \& Corin, N. 2000. Abundance, sources and speciation of trace elements in humus-rich streams affected by acid sulphate soils. Aquatic Geochemistry 6: 367-383.

Åström, M. \& Spiro, B. 2000. Impact of isostatic uplift and ditching of sulfidic sediments on the hydrochemistry of major and trace elements and sulfur isotope ratios in streams, western Finland. Environmental Science and Technology 34: 1182-1188.

Bishop, K., Laudon, H. \& Köhler, S. 2000. Separating the natural and anthropogenic components of spring flood $\mathrm{pH}$ decline: A method for areas that are not chronically acidified. Water Resources Research 36: 1873-1884.

Coleman, M.L. \& Moore, M.P. 1978. Direct reduction of sulfates to sulfur dioxide for isotopic analysis. Analytical Chemistry 50: 1594-1595.

Edén, P. \& Björklund, A. 1993. Hydrogeochemistry of river waters in Fennoscandia. Aqua Fennica 23: 125-142.

Edén, P., Weppling, K. \& Jokela, S. 1999. Natural and landuse induced load of acidity, metals, humus and suspended matter in Lestijoki, a river in western Finland. Boreal Environment Research 4: 31-43.

Hoefs, J. 1997. Stable isotope geochemistry. Springer, $201 \mathrm{p}$.

Kaplan, I.R. \& Rittenberg, S.C. 1964. Microbiological fractionation of sulphur isotopes. Journal General Microbiology 34: 195-212.

Kortelainen, P. 1993. Content of total organic carbon in Finnish lakes and its relationship to catchment charac- 
Vol. 14 (2005): 34-43.

teristics. Canadian Journal of Fisheries and Aquatic Sciences 50: 1477-1483.

Kortelainen, P. \& Mannio, J. 1990. Organic acidity in Finnish lakes. In: Kauppi et al. (eds.). Acidification in Finland. Springer-Verlag Berlin Heidelberg. p. 849-863.

Kortelainen, P. \& Mannio, J. 1998. Natural and anthropogenic acidity sources for Finnish lakes. Water, Air and Soil Pollution 42: 341-352.

Kortelainen, P. \& Saukkonen, S. 1992. Leaching of organic carbon and nitrogen from peatland-dominated catchments. Suo - Mires and Peat 43: 221-225.

Kortelainen, P. \& Saukkonen, S. 1995. Organic vs. minerogenic acidity in headwater streams in Finland. Water, Air and Soil Pollution 85: 559-564.

Kortelainen, P. \& Saukkonen, S. 1998. Leaching of nutrients, organic carbon and iron from Finnish forestry land. Water, Air and Soil Pollution 105: 239-250.

Lahermo, P., Salminen, R., Tarvainen, T. \& Väänänen, P. 1995. Geochemical mapping of stream waters and sediments in Finland. Geological Survey of Finland, Special Paper 20: 155-166.

Lahermo, P., Väänänen, P., Tarvainen, T. \& Salminen, R. 1996. Geochemical atlas of Finland, part 3: Environmental geochemistry - stream waters and sediments. Geological Survey of Finland, Esbo, Finland.

Laudon, H. \& Bishop, K.H. 1999. Quantifying source of acid neutralisation capacity depression during spring flood episodes in northern Sweden. Environmental Pollution 105: 427-435.

Laudon, H., Westling, O. \& Bishop, K. 2000. Cause of pH decline in stream water during spring melt runoff in northern Sweden. Canadian Journal of Fisheries and Aquatic Sciences 57: 1888-1900.

Nakai, N. \& Jensen, M.L. 1964. The kinetic isotope effect in the bacterial reduction and oxidation of sulphur. Geochimica et Cosmochimica Acta 28: 1893-1912.

Öborn, I. 1989. Properties and classification of some acid sulfate soils in Sweden. Geoderma 45: 197-219.

Palko, J. 1994. Acid sulphate soils and their agricultural and environmental problems in Finland. Acta Universitatis
Ouluensis Series C 75. University of Oulu, Finland. p. 58. (PhD-thesis).

Palko, J. \& Weppling, K. 1995. Modelling the effects of acid sulphate soils on river acidity in Finland. Nordic Hydrology 26: 37-54.

Palko, J. \& Yli-Halla, M. 1993. Assessment and management of acidity release upon drainage of acid sulphate soils in Finland. In: Dent, D.L. \& van Mensvoort, M.E.F. (eds). Selected papers of the Ho Chi Minh City symposium on acid sulphate soils. International Institute for Land Reclamation and Improvement Publication, No. 53. p. 411-418.

Rollinson, H.R. 1993. Using geochemical data: evaluation, presentation, interpretation. Longman Scientific and Technical. $329 \mathrm{p}$.

van Breemen, N. 1973. Soil forming processes in acid sulphate soils. In: Dost, $\mathrm{H}$ (ed.). Proceedings of the international symposium on acid sulphate soils. International Institute for Land Reclamation and Improvement Publication, No. 18. p. 66-130.

van Breemen, N. 1993. Environmental aspects of acid sulphate soils. In: Dent, D.L. \& van Mensvoort, M.E.F. (eds). Selected papers of the Ho Chi Minh City symposium on acid sulphate soils. International Institute for Land Reclamation and Improvement Publication, No. 53. p. 391-402.

Weppling, K. 1993. Hydrochemical factors affecting the neutralization demand in acid sulphate waters. Vatten 49: 161-170.

Wiklander, L., Hallgren, G. \& Jonsson, E. 1950. Studies on gyttja soils: III. rate of sulfur oxidation. The Annals of the Royal Agricultural College of Sweden 17: 425440.

Yli-Halla, M. 1997. Classification of acid sulphate soils in Finland according to Soil Taxonomy and the FAO/ Unesco legend. Agricultural and Food Science in Finland 6: 247-258.

Yli-Halla, M., Puustinen, M. \& Koskiaho, J. 1999. Area of cultivated acid sulfate soils in Finland. Soil Use and Management 15: 62-67. 